\title{
INTER-ORGANIZATIONAL COLLABORATION FOR INNOVATION IN MANUFACTURING FIRMS
}

\section{Bojan Lalić, Nemanja Tasić, Uglješa Marjanović, Milan Delić \&Nela Cvetković}
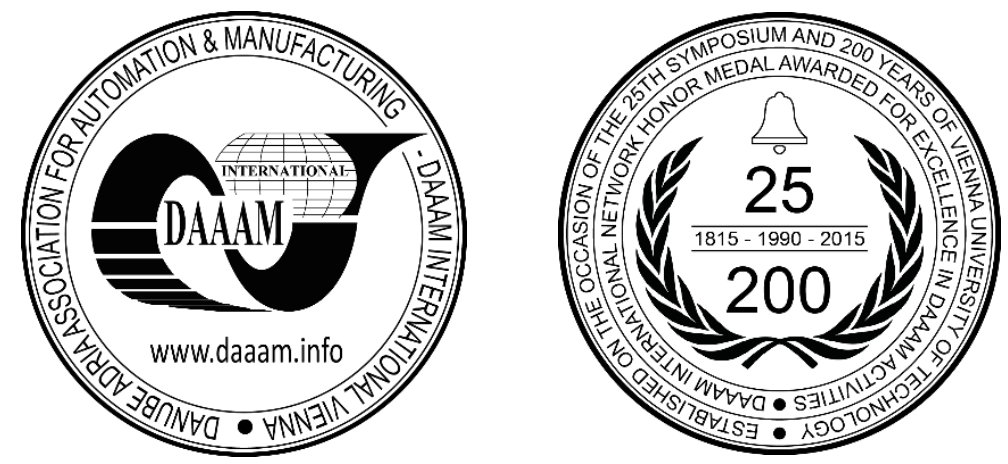

This Publication has to be referred as: Lalic, B[ojan]; Tasic, N[emanja]; Marjanovic, U[gljesa]; Delic, M[ilan] \& Cvetkovic, N[ela] (2016). Inter-Organizational Collaboration for Innovation in Manufacturing Firms, Proceedings of the 27th DAAAM International Symposium, pp.0721-0729, B. Katalinic (Ed.), Published by DAAAM International, ISBN 978-3-902734-08-2, ISSN 1726-9679, Vienna, Austria

DOI: $10.2507 / 27$ th.daaam.proceedings.104

\begin{abstract}
From day to day, taking part in the collaboration process in different business aspects, especially in the innovation process continues to gain in importance. Innovation enables companies to strive for a more powerful market position, while interorganizational cooperation is perceived as an efficient means of enhancement of firm innovativeness.

The purpose of this paper is to present the state of inter-organizational collaboration for innovation among manufacturing companies in Vojvodina, analyzing cooperation among manufacturing firms with different external parties, in different innovation areas. Furthermore, the aim is to examine the effects of inter-organizational collaboration on the innovativeness of manufacturing firms in Vojvodina.

The data used in this paper was gathered within the international project European Manufacturing Survey.

The results are presented using descriptive statistics and they demonstrate that the existence and frequency of interorganizational collaboration, although quite present, depends on external parties as potential cooperation partners and on different innovation areas in which collaboration could occur. Also, the research shows there is a notable relation between inter-organizational collaboration and firm innovativeness.
\end{abstract}

Keywords: Inter-organizational collaboration; Cooperation; Manufacturing firms; Innovation; Innovativeness.

\section{Introduction}

In the present constant and dynamic changes in economic and technological conditions, inter-organizational collaboration appears as the industrial response [1]. In order to neutralize and cope with competition intensity and market heterogeneity, some companies decide to engage in joint cooperation with other firms and different organizations [2].

Various potential participants have different strategic objectives to take part in certain aspects of collaboration. Higher level of motivation in certain companies might be due to their perception of their capabilities and resources to perform various activities on their own. More specific, large companies can rely on their own resources, while small firms tend to acquire the necessary resources from the environment. However, albeit large organizations may have necessary resources, 
SMEs are often a fruitful source of innovative ideas and fresh perspectives. In practice, collaboration has shown many benefits for companies, especially in terms of innovation capacity building. However, not all organizations recognize the benefits of inter-organizational collaboration and cooperation, although the percentage of companies seeing collaboration as desirable is relatively high. This can be explained by varying organizational cultures, environmental climates and similar, influencing those differences in the understanding of the collaboration concept by different parties.

We do not have a clear understanding of how inter-organizational collaboration affects innovation in small regions such as Autonomous Province of Vojvodina. Thus, this paper deals with the collaboration concept in manufacturing companies in the territory of Vojvodina. Related to that, three research questions are defined:

- The first research question of this paper is to present the level of collaboration of manufacturing firms with other different external parties, in different areas of innovation.

- The second research target is to investigate the perception of manufacturing firms regarding the importance of different innovation areas.

- The last research target is to examine the connection between inter-firm cooperation and firm innovativeness, more precisely, to analyze whether more intensive inter-organizational cooperation in new product development activities, as well as in R\&D activities, influences the higher firm innovativeness in terms of innovative products.

For this purpose, we adopted Danneels' [3] explanation of "firm innovativeness as the outcome of the innovation process, defined as the capacity of the firm to develop and introduce a new product or service" and Dietz \& Becker's [4] view on innovation output of firms as indicated by new products. Although innovativeness could be also observed from a wider perspective (including new processes, technological concepts etc.), in this paper we used the previously described definition to investigate the existing connections between collaboration practice and innovativeness. The assumption was that a greater degree of collaboration in new product development and $R \& D$ activities results in greater innovative development capacity, specifically, new products introduction success.

The data used were gathered through the European Manufacturing Survey (EMS), covering the results from 2015 in the territory of Vojvodina where the Faculty of Technical Sciences in Novi Sad had carried out the EMS survey. The results are presented using descriptive statistics. To the extent of our knowledge, so far there are no recent studies directly addressing this perspective on the topic in Vojvodina. The results show that there is a high degree of collaboration between manufacturing companies in Vojvodina and external parties. Nonetheless, the results demonstrate that manufacturing companies collaborating more often with other organizations (companies and research institutions) in product innovation activities or R\&D have introduced a noticeably higher percentage of new products to the company and new products to the market than the companies not engaged in inter-organizational collaboration.

The paper is structured as follows. The theoretical part briefly introduces the concept of collaboration and innovation. The methodological section explains the concept of EMS and describes the process of data gathering. The empirical section analyses the level and forms of collaboration of manufacturing firms with external parties and potential connection between inter-firm cooperation and firm innovativeness. Finally, the conclusion summarizes the findings with certain implications.

\section{Collaboration and Innovation}

In their paper [5] the authors define the concept of inter-organizational collaboration as a feature of the innovation process referring to the extent to which other organizations form an important part in the innovation process, where organizations can stand for firms or for institutions.

According to [6], innovation represents 'the implementation of new or significantly improved product, process, new marketing method, or a new organizational method in business practice, workplace organization or external relation'.

Nowadays, as the highest priority in achieving competitive advantage is innovation [7], collaboration with partners, customers and competitors has become strategic imperative for companies [8].

So far, many incentives for inter-company and inter-organizational collaboration have been pointed out by different researchers and practitioners. In terms of positive effects on firm innovativeness, collaborative linkages enable all parts to exploit the benefits of knowledge sharing, to benefit from complementary skills merged from different firms [9], to take advantages of scale economies in the research process, cost sharing and risk spreading [10], [11], [12]. Furthermore, cooperation results in faster product/service development and faster speed to market [13], [14].

One of the main aims of any firm is to maximize profits by using and improving its resources and capabilities [15]. Consequently, knowledge flows and exchange are becoming essential priorities for firms. One of the most effective ways to accomplish this and improve the learning process is to cooperate with external partners [12].

SMEs are prompt for the establishment of cooperative relationships with other companies to achieve market strength, or to exploit new opportunities [12]. This could not be possible to that extent due to their limited resources, both human and financial. Although SMEs may be well innovative, they often do not have the commercial strength or professionalism required to successfully exploit their innovative ideas [16]. Related to that, the success of an organization is not guaranteed only by the ability to understand and generated advanced knowledge, but also to transfer it into marketable innovation as well [17]. On the other hand, large companies are less interested in cooperation for innovation, due to the fact they possess the needed technical and financial capability [11]. However, in practice, there is significant evidence that the global 
market leaders recognize the necessity to find cooperation partners to design an innovative value chain, combining their own core competencies with those of other leading firms [18]. Fostering mutual trust as a basis of cooperation, companies are able to exchange resources and key competences to achieve the goals unreachable when acting individually [19].

The decision to cooperate in innovation is significantly driven by the fact that cooperation is seen as an efficient way to enhance the probability of innovation project success [20], [4]. This is in direct relation to the belief that the implementation of additional external capacities raises the level of innovation output [4]. Nonetheless, analyses of the effect of cooperation demonstrate that, on average, cooperative firms have higher overall performance levels than noncooperative ones [4] as well as higher R\&D intensity [21].

\section{Research methodology}

The research methodology used was a survey research. Specifically, data was collected through The European Manufacturing Survey (EMS), coordinated by the Fraunhofer Institute for Systems and Innovation Research - ISI. EMS represents the largest European survey of manufacturing activities whose extensive questionnaire covers questions generally referring to organizational concepts, collaboration for innovation, cooperation issues, the application of advanced technologies and innovative concepts, project management, performance indicators and others. The main focus of the survey is the development and utilization of different types of innovations by companies in the manufacturing industries, and associated performance effects. In 2001, researchers at ISI took the initiative to make an international survey, aiming to gather internationally comparable data by means of a standardized method and core questionnaire that was carefully translated into each participating country's local language. Since then, the survey has been conducted every three years, constantly expanding the range of participating countries. So far, five multinational survey rounds have been carried out with about 3-year intervals while the sixth round is under way (2015/2016).

Our research was based on EMS data from the Serbian (territory of Vojvodina) subsample from the year 2015. The responding companies were from the manufacturing sector, having at least 20 employees. The total number of companies meeting the requirements in Vojvodina is 600 . However, in order to ensure a representative sample of companies equally distributed by different industries and counties, 334 questionnaires had been sent, 123 of which were returned (36.8\% response rate). Data gathering was performed by the Faculty of Technical Sciences in Novi Sad, firstly through the pretest phase and two phases of mass distribution.

The information asked for and analyzed concerns the following:

- Existence of collaboration with external parties (suppliers, competitors, service organization and research centers and universities) in specific innovation areas (new products, new technical processes, new product related services and new organizational concepts).

- Cooperation in R\&D with other organizations (suppliers, competitors, service organization and research centers and universities).

- New product development.

- Relevance of different innovation areas for manufacturing companies.

All questions were carefully translated from the original sample and adjusted to the specificities of the territory where the survey was conducted. An example of one question related to the main sources of innovative ideas for manufacturing companies in Vojvodina is presented in figure 1.

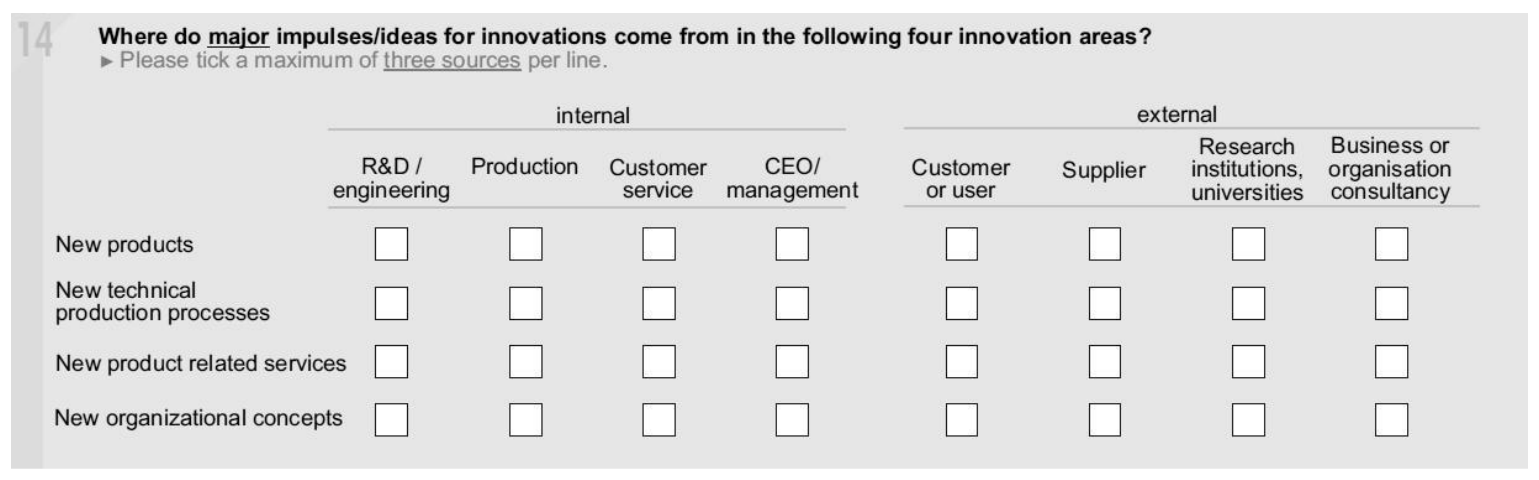

Fig.1. Question on innovation process in EMS 2015.

\section{Results}

For the purpose of testing research questions, descriptive statistics was conducted by IBM SPSS.

\subsection{Inter-organizational cooperation in specific innovation areas}

Firstly, the percentage of companies that collaborate with other organizations or parties in specific innovation areas is analyzed and presented. The defined areas of innovation in this survey are: new products, new technical production 
processes, new product related services and new organizational concepts. Following, figure 2 shows the percentage of manufacturing companies in Vojvodina according to the external party they cooperate with in specific innovation areas, those parties being: customers, suppliers, competitors, service organizations (business or organization consultancy) and research institutions and universities. Finally, the frequency of collaboration is presented in figure 3.

Table 1 presents the percentage of Vojvodina's manufacturing companies that cooperate with external organizations in specific innovation areas.

\begin{tabular}{|l|l|l|}
\hline Innovation area & Share & Rank \\
\hline New products & $69.1 \%$ & 1 \\
New technical production process & $58.5 \%$ & 2 \\
New product related services & $50.4 \%$ & 3 \\
New organizational concepts & $37.4 \%$ & 4 \\
\hline
\end{tabular}

Table 1. Share of manufacturing companies in Vojvodina that cooperate with external organizations in specific innovation areas.

The analysis demonstrates that organizations collaborate with other organizations and external parties mostly in the domain of product innovation (69.1\% of respondents). Furthermore, in the case of innovation areas such as technical production process innovation and product related services innovation, the number of companies cooperating is also above $50 \%$ (58.5\% and 50.4\% respectively). The lowest share of manufacturing companies that collaborate with external parties is in the field of organizational concepts innovation (37.4\%).

Following, figure 2 contains the percentage of manufacturing companies in Vojvodina collaborating with different external parties regarding each of the specific innovation areas.

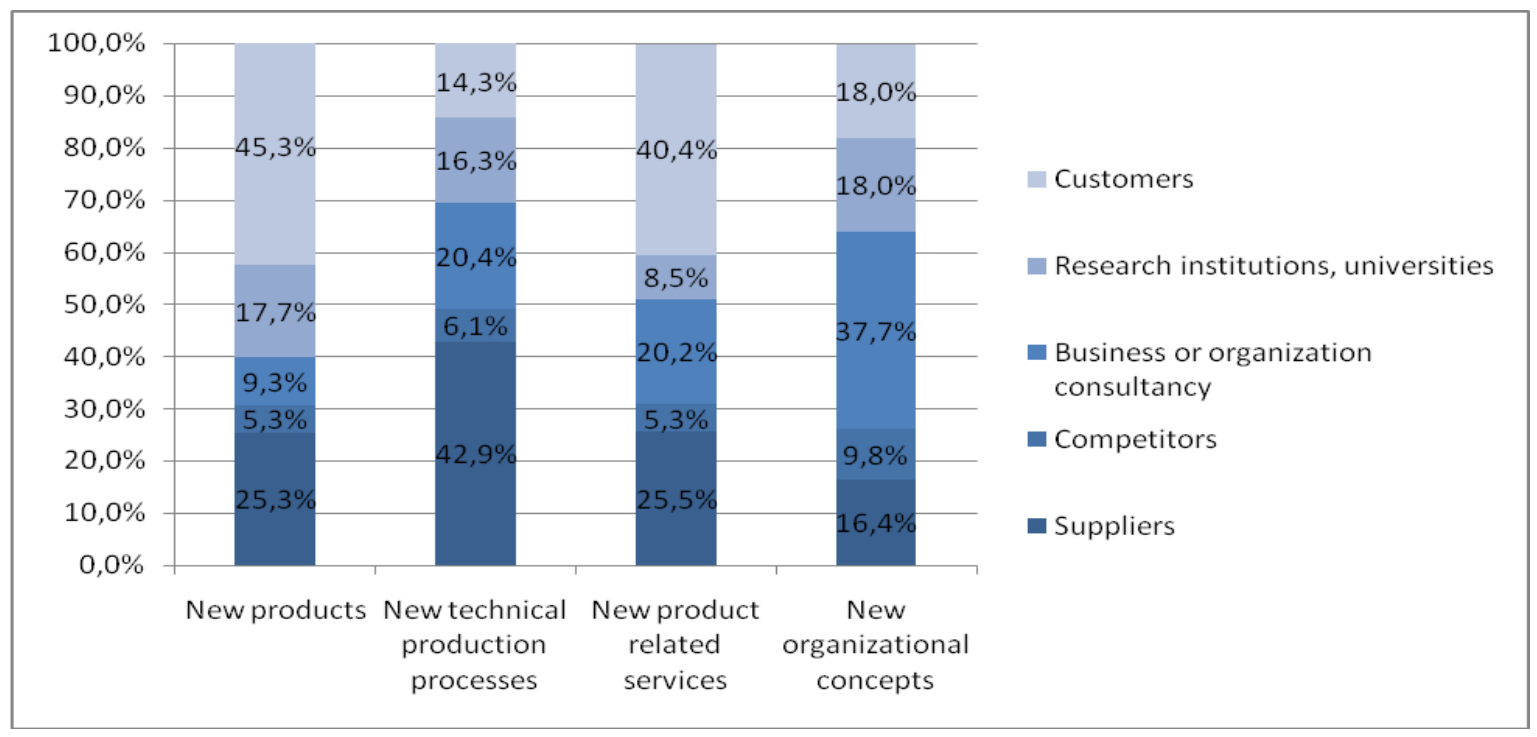

Figure 2.The percentage of manufacturing companies in Vojvodina collaborating with different external parties regarding each of the specific innovation areas.

Regarding new product development, manufacturing firms in Vojvodina mostly cooperate with their customers $(45.3 \%)$, and with their suppliers in the second place $(25.3 \%)$. When it comes to innovation in terms of technical production processes, companies cooperate by far most frequently with their suppliers (42.9\%). In the area of new product related services the most frequent partner in cooperation activities are customers (40.4\%) and following, suppliers $(25.5 \%)$. Finally, most of the companies have marked business or organization consultancy as their collaboration partner in new organizational concepts development $(37.7 \%)$.

In each of the specific areas of innovation, the lowest share of manufacturing companies has pointed out competitors as their collaborative partners. This may be explained by the insecurity of firms when it comes to sharing their specific knowledge, expertise or internal processes to the competitors and by the fact that every collaboration process requires intensive management of knowledge and information flows which increases in case of cooperation with competitors.

Figure 3 contains the frequency of collaboration of manufacturing companies in Vojvodina with different external parties regarding each of the specific innovation areas. 


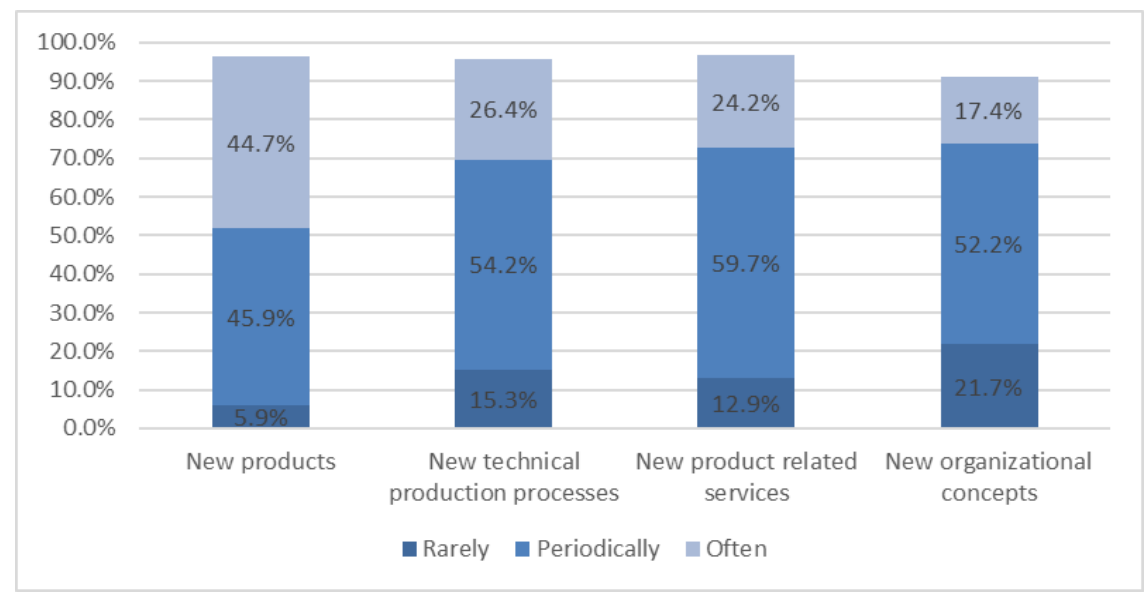

Figure 3. The frequency of collaboration of manufacturing companies in Vojvodina with different external parties regarding each of the specific innovation areas.

Figure 3 shows that the majority of the respondents reporting that collaboration of their firm with other companies or organizations exists, have also defined the frequency of their collaboration as periodical or frequent. However, it can be observed that the frequency of inter-organizational collaboration is the most intensive in the domain of new product development, mildly decreasing in the area of new technical processes and product related services. Finally, the frequency of collaboration is lowest when it comes to the innovation of organizational concepts.

Based on results presented in Table 1, Figure 1 and Figure 2, it can be discussed that most of the manufacturing firms are cooperating with other firms, suppliers, buyers, competitors and research institutions in the area on new product development $(69.1 \%)$. Furthermore, the most common partners in collaboration for innovation of products or services are buyers (45.3\%). Also, the results show that manufacturing firms are choosing different partners regarding different areas of innovation. Compared to the results from similar studies, there is notable difference. While in Vojvodina most manufacturing firms tend to develop stronger cooperation relationship with suppliers and buyers, in developed European countries most of the manufacturing firms are leaning towards more intensive cooperation with research institutions. Nonetheless, the same study shows that manufacturing firms in developed European countries are more often cooperating in new technical production processes development, new product related services development and new organizational concepts [22].

\subsection{Importance of different innovation areas for manufacturing companies in Vojvodina}

Figure 4 demonstrates the evaluation of importance of different innovation areas for manufacturing companies in Vojvodina. Manufacturing companies participating in EMS were asked to assess and rank 4 domains of innovation activities (improvement of product offer with related services, new organizational concepts, new technological production processes and new product development) in terms of their importance for their companies. Companies were evaluating using a scale 1-4, where 1 is the most important and 4 the least important innovation area for them.

Manufacturing companies have assessed new product development as the most important innovation domain for their firm and business. That is one of the reasons why more attention is dedicated to this innovation area in the next sections.

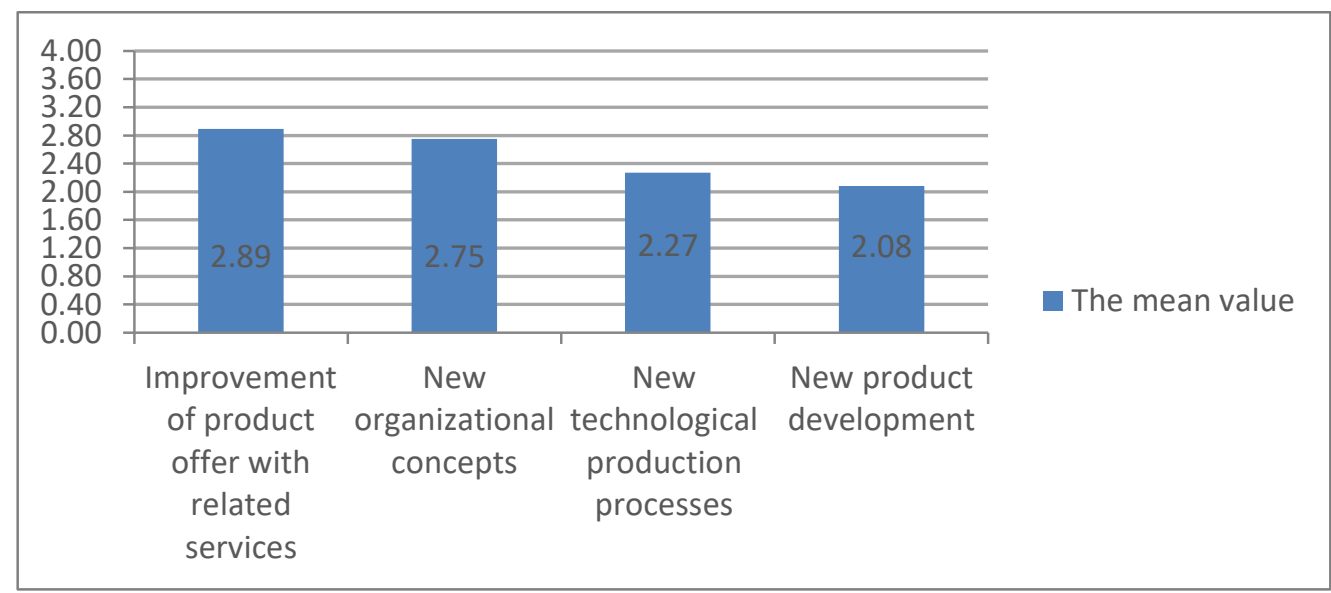

Figure 4. Innovation areas ranked by the importance for manufacturing firms 


\subsection{Inter-organizational collaboration in product innovation activities}

The last research aim is to examine if there was a connection between the existence of inter-firm collaboration and the capability for new product development, as an aspect of innovativeness. In other words, the goal was to analyse if firms cooperating with other organizations in new product development activities have increased innovativeness in terms of new products development. In order to achieve that, the percentage of companies that have introduced innovative products to the firm and to the market in the last 4 years has been compared considering whether those firms are cooperating with other organizations in product innovation activities or not.

New product development requires interdisciplinary approach which can only be achieved by linking firms with other actors [23]. So far, firms where cooperation for innovation is common practice have been introducing innovations new not only to the firm, but also to the market 11] and in the same time with the opportunity to accelerate the process of product development through collaboration [24]. The main assumption is that the firms collaborating with external parties in the field of product innovation and in $\mathrm{R} \& \mathrm{D}$ innovate their products more often than the companies that do not cooperate or do so only rarely, both in the firm and on the market.

The analysis showed that $65 \%$ of manufacturing companies in Vojvodina claiming they are collaborating with other organizations in the new product development, have introduced new products since 2012, out of which almost $30 \%$ are innovations to the market. On the other hand, $25 \%$ of firms claiming they do not cooperate in the area of product innovation have introduced new products to the firm and only 5\% new to the market. Considering this, the assumption that firms collaborating with external parties in the field of product innovation innovate their products more often than the companies that do not cooperate or do so rarely, both in the firm and market has been confirmed in the case of manufacturing companies in Vojvodina.

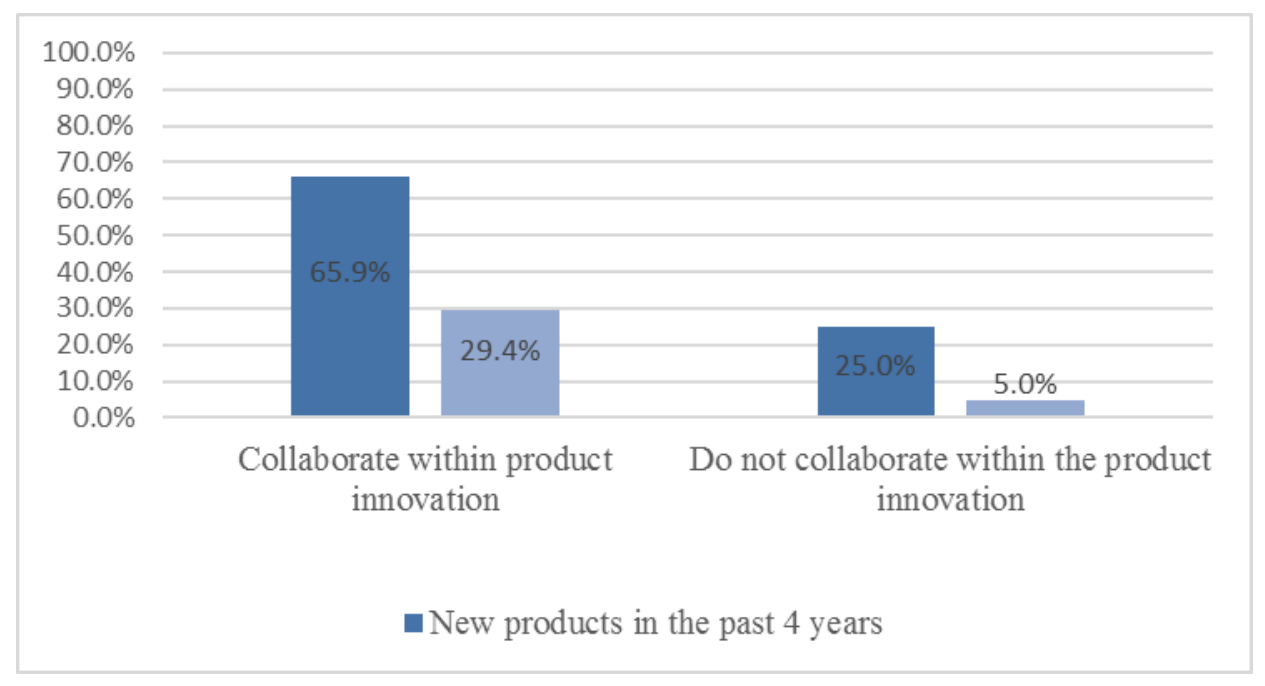

Figure 5. Connection between the existence of inter-organization collaboration and product innovation

\subsection{Inter-organizational collaboration in $R \& D$ and firm innovativeness}

Cooperation activities are considered as efficient means for the industrial organization of complex R\&D and innovation process [11]. As companies are experiencing pressure in terms of shortened time from an innovative idea to its commercial success, they are realizing that R\&D activities could not be performed on their own, but rather through acquiring knowledge and ideas from other companies and institutions [7]. Furthermore, it is perceived that cooperation increases the profitability of research and development [25].

One of the incentives for undertaking collaborative research and development with other firms or institutions is the fact that the capacity of a company to absorb and exploit the knowledge from the external environment has a positive effect on the probability of being a successful innovator [21]. As innovation activity is considered directly related to the amount of money companies spend on R\&D activities [25] it is expected that firm collaboration and joint investment in $R \& D$ will result in higher innovation capacity. Generally, firms engaged in the innovation process are recognizing the necessity of taking part in R\&D cooperation in order to obtain expertise which could not be generated in-house. Considering that, $R \& D$ collaboration with other companies and institutions is seen as the crucial way to make external resources available and usable, since it enables efficient knowledge transfer, resource exchange and organizational learning [4]. Finally, most commonly innovations are associated with research and development activities of the products [27].

Taking the previously mentioned into consideration, it seemed important to analyse the practice of R\&D interorganizational collaboration in Vojvodina, in order to present the degree of existence and frequency of such practice. 
Furthermore, the assumption was that the firms claiming they have introduced a new innovative product in the last four years will mostly be those taking part in R\&D cooperation. This hypothesis is based on the fact that the absorption of external resources through such cooperation leads to an extension of firms' capabilities of developing new products.

To analyze if firms cooperating with other organizations R\&D activities are more innovative in terms of new products development, the percentage of companies that have introduced innovative products to the firm and to the market in the last 4 years has been compared considering whether those firms are cooperating with other organizations in research and development activities or not.

Figure 6 shows comparison between the percentage of manufacturing firms having introduced new products in the firm and to the market in the last four years depending on whether they collaborate in R\&D or not.

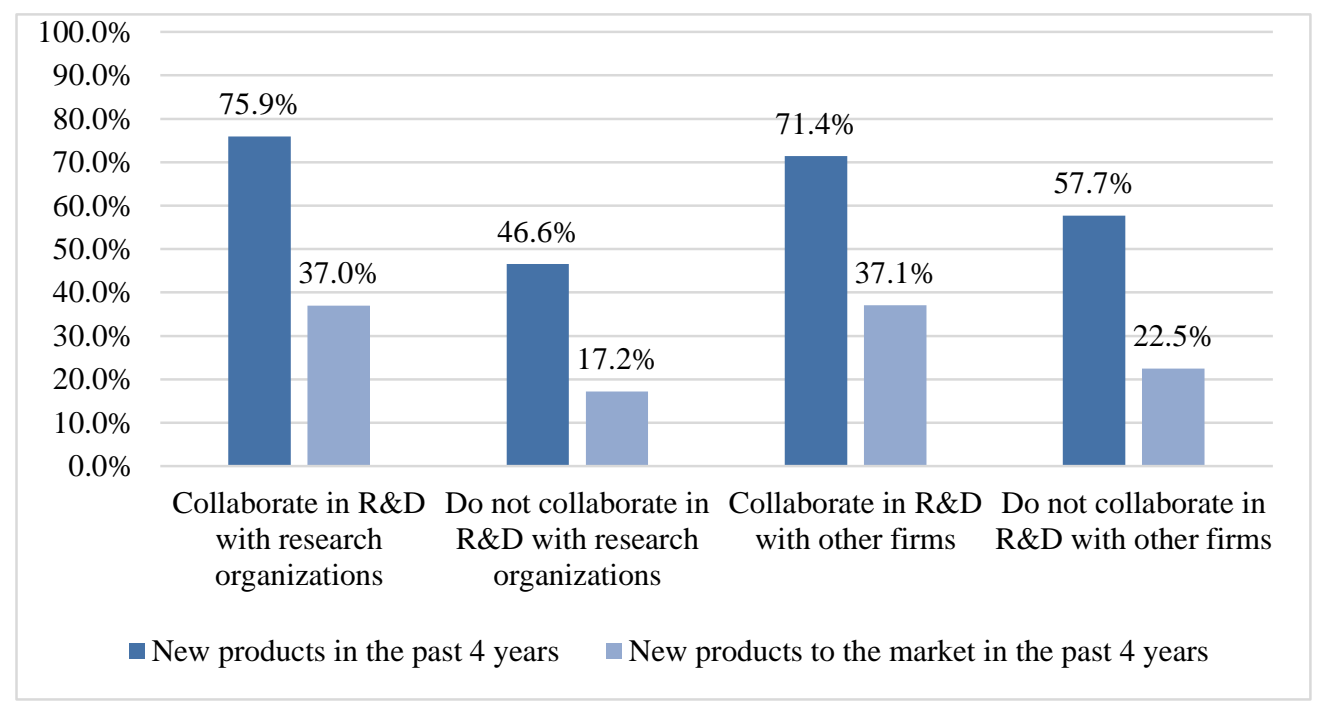

Figure 6. Connection between the existence of inter-organization R\&D collaboration and product innovation

Regarding the firms collaborating in R\&D, a high level of product innovations was observed. $75.9 \%$ of companies cooperating in $\mathrm{R} \& \mathrm{D}$ with research organizations confirmed they had developed new products in the last four years, out of which almost half (37\%) were products completely new to the market. A very similar situation applies to the companies that choose to collaborate in R\&D with other firms. However, a noticeably lower percentage of manufacturing firms in Vojvodina that do not cooperate in R\&D with research organizations or other firms have introduced a new product, both to the firm and to the market, demonstrating that there is considerable difference in innovativeness between manufacturing firms collaborating in R\&D and those not collaborating with other firms or research organizations.

Similar study covering European countries are aligned with the results presented in Figure 5 and Figure 6. Companies cooperating with other firms in R\&D and product innovation activities demonstrate higher innovativeness in terms of new products commercialization. The European manufacturing companies show the increase of interest in collaboration in $R \& D$ and product innovation activities, since it had proved to be an efficient mean for the improvement of innovativeness [5]. Furthermore, the study shows that the percentage of European manufacturing companies engaging in collaboration for innovation increases more rapidly than in the past.

\section{Conclusion}

In this paper we have analyzed and presented the state of collaboration between manufacturing companies in Serbia and other firms or organizations in terms of innovation activities. The research questions are to investigate level and frequency of collaboration of manufacturing firms with other different external parties, in different areas of innovation, to investigate the perception of manufacturing firms regarding the importance of different innovation areas, and finally, to examine whether the more intensive inter-organizational cooperation in new product development and R\&D activities influences the higher firm innovativeness in terms of innovative products.

To analyze previously mentioned issues, EMS (European Manufacturing Survey) was conducted and results were presented with descriptive statistics.

The results show that there is a high level of cooperation with customers, suppliers, business consultancy and research institutions. Collaboration with competitors in different areas of innovation exists, however, it is on a notably lower level 
than with the previously mentioned external parties. Out of four defined areas of innovation: new product development, new technological production processes, new organizational concepts and new product related services, interorganizational cooperation most frequently occurs in product innovation activities. Additionally, product innovations have been emphasized as the most important area for manufacturing firms business.

Furthermore, the analysis demonstrates that manufacturing companies collaborating with other organizations in product development and R\&D activities are notable more innovative, in terms of innovative products, than companies that are not collaborating. In case of manufacturing firms declared as participants in product innovation activities, a considerably higher percentage of them had introduced new products to the firm $(65,9 \%)$ and to the market $(29,4 \%)$, than firms not engaging in cooperation with other companies or institutions (25\% and 5\%, respectively). Moreover, when it comes to the companies cooperating in R\&D activities, in average $73 \%$ of them had introduced new products to the firm, and $37 \%$ to the market, while in average $50 \%$ of companies that are not cooperating in R\&D have introduced new product to the firm out of which only around $20 \%$ have introduced products new to the market. Considering that, it can be said that there is a strong bond between inter-organizational collaboration and innovativeness in the case of manufacturing firms in Vojvodina. Therefore, firms tending to strengthen their market position and competitiveness through improvement of their innovativeness should cooperate with other firms, suppliers, research organizations, buyers and competitors.

In this paper the location of collaboration partners was not taken in consideration. Related to that, as further research question we see investigation of influence of partners' location on collaboration forms, frequency, success and similar.

\section{References}

[1] Smith, H.L., Dickson, K. \& Smith, S.L., (1991). “ There are two sides to every story ” : Innovation and collaboration within networks of large and small firms. Research Policy, Vol. 20., 1991, pp.457-468

[2] Lee, S.M., Olson, D.L. \& Trimi, S., (2012). Co-innovation: convergenomics, collaboration, and co-creation for organizational values. Management decision, Vol. 50., No. 5., 2012, pp.817-831

[3] Danneels, E., (2002). The dynamics of product and firm competences. Strategic Management Journal, Vol. 23, 2002, pp.1095-1121

[4] Becker, W. \& Dietz, J., (2004). R\&D cooperation and innovation activities of firms-evidence for the German manufacturing industry. Research Policy, Vol. 33., No. 2, 2004, pp.209-223

[5] Alexiev, A.S., Volberda, H.W. \& Van den Bosch, (2016). Interorganizational collaboration and firm innovativeness: Unpacking the role of the organizational environment. Journal of Business Research, Vol. 69., pp. 974-984

[6] Trifan, L., Guica R.-I. \& Micu, C., (2012). Entrepreneurial creativity and innovation management in engineering: Proceedings of DAAAM International 2012, pp. 783-789

[7] Fajsi, A., Tekic, Z. \& Moraca, S., (2016). Open innovation in manufacturing SMEs- integration into Value Networks: Proceedings of DAAAM International 2012, pp. 1076-1081

[8] Orcik, A., Anisic, Z. \& Cosic, I., (2012). Collaboration and new product development in PLM environment: Annals and Proceedings of DAAAM International 2012, pp. 1091-1094

[9] Ahuja, G., (2000). Collaboration Networks, Structural Holes, and Innovation: A Longitudinal Study. Administrative Science Quarterly, Vol. 45., No. 3, 2000, pp.425-455

[10] Lopez, A., (2008). Determinants of R\&D cooperation: Evidence from Spanish manufacturing firms. International Journal of Industrial Organization. Vol 26., 2008, pp. 113-136

[11] Cassiman, B. et al., (2002). R\&D Cooperation and Spillovers: Some Empirical Evidence from Belgium. The American Economic Review, Vol. 92., No. 4., 2002, pp.1169-1190

[12] De Faria, P., Lima, F. \& Santos, R., (2010). Cooperation in innovation activities: The importance of partners. Research Policy, Vol. 39, 2010, pp.1082-1092

[13] Hwee, S., (2008). Competitive intensity and collaboration: Impact on firm growth across technological environments. Strategic Management Journal, Vol. 29, 2008, pp.1057-1075

[14] Barringer, B.R. \& Harrison, J.S., (2000). Walking a Tightrope: Creating Value Through Interorganizational Relationships. Journal of Management, Vol.26., No 3., 2000, pp. 367-403

[15] Tsang, E.W.K., (2000). Transaction Cost and Resource-Based Explanations of Joint Ventures: A Comparison and Synthesis. Organization Studies, Vol. 21., No. 1., 2000, pp.215-242

[16] Konsti-Laakso, S., Pihkala, T. \& Kraus, S., (2012). Facilitating SME innovation capability through business networking. Creativity and Innovation Management, Vol. 21., No. 1., 2012, pp.93-105

[17] Tekić, Ž., Ćosić, I. \& Katalinić, B., (2011). Innovation and knowledge creation mechanisms. In Annals \& Proceedings of DAAAM International 2011. pp. 419-421 
[18] Tapscott, D. \& Williams, A., (2006). Wikinomics How Mass Collaboration Changes Everything, N. Y. Portfolio., New York

[19] Milovanović, B.M., Primorac, D. \& Kozina, G., (2016). Two-dimensional analysis of the influence of strategic networking on entrepreneurial orientation and business performance among SMEs. Tehnicki vjesnik - Technical Gazette, Vol. 23., No. 1., pp.247-255

[20] Abramovsky, L. et al., (2005). Understanding co-operative R\&D activity: Evidence from four European countries, The Institute for Fiscal Studies

[21] Sampson, R.C., (2007). R\&D alliances and firm performance: the impact of technological diversity and alliance organization on innovation. Academy of Management Journal, Vol. 50., No. 2., pp.364-386.

[22] Robin, S. \& Schubert T., (2010). Cooperation with public research institutions and success in innovation. Evidence from France and Germany. Fraunhofer ISI Discussion Papers Innovation System and Policy Analysis. Vol. 24.

[23] Palcic, I. et al., (2010). Manufacturing firms ' cooperation patterns - experiences from Slovenia and Spain. Advances in Production Engineering \& Management, Vol. 5., No. 4, pp.253-261

[24] Wu, S. B., Gu, X., Wu, G.D., Zhou, Q., (2016). Cooperative R\&D contract of supply chain considering the quality of product innovation. International Journal of Simulation Modelling. Vol. 15., No. 2., 341-351

[25] Belderbos, R., (2004). Heterogeneity in R\&D cooperation strategies. International Journal of Industrial Organization, Vol. 22., No. 8-9, pp.1237-1263.

[26] Palcic, I., Buchmeister, B. \& Polajnar, A., (2010). Analysis of innovation concepts in slovenian manufacturing companies. Strojniski Vestnik/Journal of Mechanical Engineering. Vol. 56., No. 12. pp. 803-810

[27] Koren, R. \& Palcic, I., (2015). The impact of technical and organisational innovation concepts on product characteristics. Advances in Production Engineering \& Management, Vol. 10., No. 1, pp. 27-39 